\title{
Body Mass Index and Associated Factors of Obesity and Underweight in a General Out-patient Population in a Tertiary Hospital in Nigeria
}

\author{
Ernest Ndukaife Anyabolu $1,2,3$ \\ ${ }^{1}$ Department of Medicine, Imo State University Teaching Hospital, Orlu, Nigeria \\ ${ }^{2}$ Department of Medicine, Federal Medical Centre, Owerri, Nigeria \\ ${ }^{3}$ Department of Medicine, Chukwuemeka Odumegwu Ojukwu University Teaching Hospital, Awka, Nigeria
}

Email address:

enhealer@yahoo.com

\section{To cite this article:}

Ernest Ndukaife Anyabolu. Body Mass Index and Associated Factors of Obesity and Underweight in a General Out-patient Population in a Tertiary Hospital in Nigeria. American Journal of Internal Medicine. Vol. 4, No. 5, 2016, pp. 85-92. doi: 10.11648/j.ajim.20160405.12

Received: October 5, 2016; Accepted: October 13, 2016; Published: November 7, 2016

\begin{abstract}
There is increasing incidence of abnormal weight changes in Sub-Saharan Africa, including Nigeria. Factors which influence body mass index (BMI) in developing countries have not been completely identified. Weight changes may be observed even in general out patients, unrelated to the major complaints for which the patients are presenting in clinics. This study was set out to evaluate BMI and potential risk factors of underweight and obesity in subjects attending the general outpatient clinic in Federal Medical Centre, Owerri, Nigeria. This was a cross-sectional study conducted on general out patients. Body mass index was determined. Relevant investigations were performed. Association of weight changes with their potential risk factors and the strength of variables to predict BMI, underweight and obesity were determined. The mean BMI of the subjects was $25.5 \pm 6.5 \mathrm{~kg} / \mathrm{m}^{2}$. Underweight was present in $14(10.3 \%)$, normal weight in 57(41.9\%), overweight in 24(17.6\%) and obesity in $41(30.1 \%)$ of the subjects. There was significant association between BMI and hemoglobin (Hb), 24-hour urine osmolality (24HUOsm), serum cholesterol, serum low density lipoprotein cholesterol (LDL), serum high density lipoprotein cholesterol (HDL), as well as serum triglyceride. There was significant but poor correlation between BMI and spot urine protein (SUP), spot urine creatinine (SUCr), spot urine osmolality (SUOsm), serum cholesterol, serum triglyceride, serum $\mathrm{HDL}$, serum LDL, as well as Hb. Spot urine protein, SUOsm, and Hb predicted BMI. Furthermore, SUOsm, serum cholesterol, serum HDL and serum LDL predicted obesity. The prevalence of underweight $(10.3 \%)$ and obesity $(30.1 \%)$ were high in the general out patients. Abnormalities of serum lipids, proteinuric renal disease with dilute urine were common in these subjects. There is a need for clinicians to routinely assess BMI and further search for anemia, dyslipidemia and renal damage in subjects with underweight and obesity attending the general out-patient clinics.
\end{abstract}

Keywords: Body Mass Index, Underweight and Obesity, Serum Lipids, Anemia, Urine Protein, Dilute Urine, General out Patients, Nigeria

\section{Introduction}

Worldwide, obesity is an increasing healthcare problem. $[1,2]$ Obesity has previously been an apparent problem of developed nations, associated with diseases like diabetes mellitus, hypertension and high socioeconomic status, while underweight has been seemingly consigned to developing countries associated with under-nutrition and infections. [3, $4,5,6]$

Studies have shown a trend in the epidemiology of obesity: the low and middle income groups have high incidence of obesity in the developed nations while in the developing countries the incidence is rising among people of high economic status, urban dwellers and even rural dwellers. [7, 8 , 9] Under-nutrition is high among rural dwellers in developing countries. [10]

The prevalence of overweight was $62 \%$ and obesity $26 \%$ for both sexes in the World Health Organization (WHO) 
region of the Americas, compared to overweight of $14 \%$ and obesity 3\% in South East Asia. [11]

In Nigeria, the prevalence of overweight ranged from $20.3 \%-35 / 1 \%$ and obesity $8.1 \%-22.3 \%$ in adults. [12, 13 , 14, 15] Two Nigerian studies reported underweight prevalence of $2.5 \%$ and $5.0 \%$. [13, 16]

Factors associated with obesity included: sex, leisure-time, physical exercise, (and educational level appear to influence obesity) low physical activity, high wealth index, no livestock, low animal fat consumption, high n-6 polyunsaturated fat consumption, television ownership, time spent watching television, low rurality index, high caste, older age, rural living, current smoking, lower systolic pressure, urbanization, higher systolic pressure, and diabetes. $[10,13,17,18]$ On the other hand, studies have shown that underweight was associated with low wealth index, high rurality index, low intake of n-6 PUFAs and less urbanization. [10, 18]

There is a paucity of studies on the associated factors of underweight, overweight and obesity in the general out patients in Nigeria. This has prompted us to evaluate BMI and the factors which might be associated with underweight and obesity in this group of people. This will help in identifying factors that may influence underweight and obesity with a view to instituting early interventions that will whittle down adverse outcomes in patients with underweight and obesity attending the general out-patient clinics.

\section{Materials and Methods}

This was a three-month cross-sectional study involving 136 subjects consecutively recruited from the general outpatients clinic in FMC, Owerri, Southeast Nigeria., conducted in 2011. Those included in the study were between 16-65 years. Those who were pregnant, or have known pituitary, adrenal, renal or terminal illness were excluded from the study. Informed written consent was obtained from all the subjects. Approval for this study was given by the Ethics Research Committee of the hospital.

With the aid of a questionnaire, demographic and anthropometric data were obtained. Our laboratory technicians administered the questionnaire and obtained the relevant data. Because the study was hospital-based, it was not pre-tested, as data collection was not difficult. In both English and our native languages, the aim of the study was explained to the subjects. The place of domicile and origin, age and gender were obtained. Height and weight were measured and BMI determined as the ratio of weight $/$ height $^{2}$ $\left(\mathrm{kg} / \mathrm{m}^{2}\right)$.

Clear instructions were given to all the subjects on how to collect 24-hour urine sample. A day-time random spot urine sample and blood samples were collected at the end of the 24-hour urine sample collection. [19, 20]

From the random spot urine samples collected, spot urine protein (SUP), spot urine creatinine (SUCr) and spot urine osmolality (SUOsm) were performed. Also from the 24hour urine samples collected, 24-hour urine protein (24HUP), 24-hour urine creatinine (24HUCr) and 24-hour urine osmolality (24HUOsm) were performed. Hemoglobin $(\mathrm{Hb})$ and serum creatinine were performed on the blood samples collected. Other tests done from the blood samples were HIV screening test, fasting serum lipid profile (FSLP) (total cholesterol, triglyceride, high density lipoprotein cholesterol (HDL), low density lipoprotein cholesterol (LDL). Osmolality was determined by freezing point depression method using Precision Osmette 5002 osmometer, creatinine by modified Jeff's method and protein by photometric method. Creatinine clearance $(\mathrm{ClCr})$ was determined. [19, 20, 21]

Statistical Analyses:

SPSS version 17.0 (SPSS Int. Chicago, II, USA) was used in analyzing the data. The distribution and characterization of clinical and laboratory features among subjects with different levels of BMI were analyzed using cross-tabulation, while the statistical significance of association between these variables and different levels of BMI was determined using student t-test. Multivariate linear regression analyses were used to determine the strength of variables to predict BMI, underweight and obesity. $\mathrm{P} \leq 0.05$ was taken as statistically significant.

Definition of terms:

WHO classification was used to define BMI levels as follows: [22]

Underweight $=<18.5 \mathrm{~kg} / \mathrm{m}^{2}$, normal weight $=18.5$ $24.9 \mathrm{~kg} / \mathrm{m}^{2}$, overweight $=25.0-29.9 \mathrm{~kg} / \mathrm{m}^{2}$, obesity class I $=$ $30.0-34.9 \mathrm{~kg} / \mathrm{m}^{2}$, obesity class II $=35.0-39.9 \mathrm{~kg} / \mathrm{m}^{2}$, obesity class III $\geq 40.0 \mathrm{~kg} / \mathrm{m}^{2}$. However, in this study, obesity was defined as class I, class II and class III obesity added together.

Normal urine osmolality: 24HUOsm 300 $750 \mathrm{mOsm} / \mathrm{kgH}_{2} \mathrm{O}[21,23]$

Dilute urine: $24 \mathrm{HUOsm}<300 \mathrm{mOsm} / \mathrm{kgH}_{2} \mathrm{O}$

Concentrated urine: $24 \mathrm{HUOsm}>750 \mathrm{mOsm} / \mathrm{kgH}_{2} \mathrm{O}$.

Anemia was defined according to the WHO criteria: [24]

No anemia: $\mathrm{Hb}>13.0 \mathrm{~g} / \mathrm{dl}$ in males and $\mathrm{Hb}>12.0 \mathrm{~g} / \mathrm{dl}$ in females

Mild anemia: $\mathrm{Hb} 11-13 \mathrm{~g} / \mathrm{dl}$ in males and $\mathrm{Hb} 11-12 \mathrm{~g} / \mathrm{dl}$ in females

Moderate anemia: $\mathrm{Hb} 8-10.9 \mathrm{~g} / \mathrm{dl}$ in males and $\mathrm{Hb}$ 8$10.9 \mathrm{~g} / \mathrm{dl}$ in females

Severe anemia: $\mathrm{Hb}<8 \mathrm{~g} / \mathrm{dl}$ in males and $\mathrm{Hb}<8 \mathrm{~g} / \mathrm{dl}$ in females

However, in this study, anemia was defined as $\mathrm{Hb}<13.0 \mathrm{~g} / \mathrm{dl}$ in males and $\mathrm{Hb}<12.0 \mathrm{~g} / \mathrm{dl}$ in females.

Overall, in this study, anemia was defined as $\mathrm{Hb} \leq 12.0 \mathrm{~g} / \mathrm{dl}$.

\section{Results}

The study subjects were 136; males were $38(27.9 \%)$ and females $98(72.1 \%)$. The mean age of the subjects was $39 \pm 12$ years. The mean values of other variables are shown in Table 1 . 
Table 1. Variables in Study subjects $n=136$.

\begin{tabular}{ll}
\hline $\begin{array}{l}\text { Variables } \\
(\text { mean } \pm \text { SD) }\end{array}$ & Subjects \\
\hline Body Mass Index $\left(\mathrm{kg} / \mathrm{m}^{2}\right)$ & $25.5 \pm 6.5$ \\
Hemoglobin $(\mathrm{g} / \mathrm{dl})$ & $12.9 \pm 1.6$ \\
Serum creatinine $(\mathrm{mg} / \mathrm{dl})$ & $0.88 \pm 0.19$ \\
SUOsm $(\mathrm{mOsm} / \mathrm{kgH} / \mathrm{O})$ & $334 \pm 204$ \\
Spot Urine Protein $(\mathrm{mg} / \mathrm{dl})$ & $7 \pm 18$ \\
Spot Urine Creatinine $(\mathrm{mg} / \mathrm{dl})$ & $148 \pm 167$ \\
24HUV(ml) & $1874 \pm 681$ \\
24-Hour Urine Creatinine (mg) & $1203 \pm 316$ \\
Creatinine Clearance (mls/min) & $93.0 \pm 41.2$ \\
24HUOsm(mOsm) & $160 \pm 133$ \\
24-Hour Urine Protein $(\mathrm{g})$ & $0.095 \pm 0.087$ \\
Serum Cholesterol (mmol/l) & $3.8 \pm 1.2$ \\
Serum LDL (mmol/l) & $2.3 \pm 1.0$ \\
Serum HDL (mmol/l) & $1.2 \pm 0.3$ \\
Serum Triglyceride (mmol/l) & $1.2 \pm 0.4$ \\
\hline
\end{tabular}

$\mathrm{SD}=$ standard deviation, $\mathrm{SUOsm}=$ spot urine osmolality, 24UOsm=24-hour urine osmolality, HDL=high density lipoprotein cholesterol, LDL=low density lipoprotein cholesterol,

Out of the 136 studied, $14(10.3 \%)$ have BMI $<18.5 \mathrm{~kg} / \mathrm{m}^{2}, 57(41.9 \%)$ have BMI $18.5-24.9 \mathrm{~kg} / \mathrm{m}^{2}, 24(17.6 \%)$ have BMI 25.0 $-29.9 \mathrm{~kg} / \mathrm{m}^{2}$, while $41(30.1 \%)$ have $\mathrm{BMI} \geq 30.0 \mathrm{~kg} / \mathrm{m}^{2}$.

There was significant association between $\mathrm{BMI}$ and $\mathrm{Hb},(\mathrm{df}=6, \mathrm{p}<0.001)$. Among 101 subjects with $\mathrm{Hb}>12.0 \mathrm{~g} / \mathrm{dl}, 5.0 \%$ has BMI $<18.5 \mathrm{~kg} / \mathrm{m}^{2}$, while $32.7 \%$ has BMI $\geq 30.0 \mathrm{~kg} / \mathrm{m}^{2}$. Out of 29 subjects with $\mathrm{Hb} 10.0-12.0 \mathrm{~g} / \mathrm{dl}, 31.0 \%$ has BMI $<18.5 \mathrm{~kg} / \mathrm{m}^{2}$ while $27.6 \%$ has BMI. $>30.0 \mathrm{~kg} / \mathrm{m}^{2}$. None of the obese or underweight subjects has $\mathrm{Hb} 7-.0-9.9 \mathrm{~g} / \mathrm{dl}$. This showed that the prevalence of anemia increased with underweight but declined with obesity (Table 2, Figure 1).

Table 2. Distribution and characterization of potential risk factors of BMI among subjects with different levels of BMI ( $n=136)$.

\begin{tabular}{|c|c|c|c|c|c|c|c|c|}
\hline \multirow{2}{*}{ Variables } & \multicolumn{4}{|c|}{ Body Mass Index Levels (no/\%) $\left(\mathrm{kg} / \mathrm{m}^{2}\right)$} & \multirow{2}{*}{$\Lambda^{2}$} & \multirow{2}{*}{ df } & \multirow{2}{*}{ LHR } & \multirow{2}{*}{ P value } \\
\hline & $<18.5$ & $18.5-24.9$ & $25.0-29.9$ & $\geq 30.0$ & & & & \\
\hline $\mathrm{Hb}(\mathrm{g} / \mathrm{dl})>12.0$ & $5(5.0 \%)$ & $39(38.6 \%)$ & $24(23.8 \%)$ & $33(32.7 \%)$ & 31.035 & 6 & $<0.001$ & $<0.001$ \\
\hline $10.0-12.0$ & $9(31.0 \%)$ & $12(41.4 \%)$ & $0(0.0 \%)$ & $8(27.6 \%)$ & & & & \\
\hline $7.0-9.9$ & $0(0.0 \%)$ & $6(100 \%)$ & $0(0.0 \%)$ & $0(0.0 \%)$ & & & & \\
\hline $24 \mathrm{HUP}<0.300 \mathrm{~g}$ & $14(12.0 \%)$ & $45(38.5 \%)$ & $22(18.8 \%)$ & $36(30.8 \%)$ & 10.671 & 9 & 0.144 & 0.299 \\
\hline$\geq 0.300 \mathrm{~g}$ & $0(0.0 \%)$ & $6(54.5 \%)$ & $2(18.2 \%)$ & $3(27.3 \%)$ & & & & \\
\hline $\begin{array}{l}\text { 24HUOsm } \\
\left(\mathrm{mOsm} / \mathrm{kgH}_{2} \mathrm{O}\right)<300\end{array}$ & $9(7.4 \%)$ & $54(44.3 \%)$ & $24(19.7 \%)$ & $35(28.7 \%)$ & 14.949 & 3 & 0.003 & 0.002 \\
\hline $300-750$ & $5(35.7 \%)$ & $3(21.4 \%)$ & $0(0.0 \%)$ & $6(42.9 \%)$ & & & & \\
\hline $\mathrm{ClCr} \geq 90 \mathrm{mls} / \mathrm{min}$ & $9(11.7 \%)$ & $28(36.4 \%)$ & $17(22.1 \%)$ & $23(29.9 \%)$ & 3.618 & 3 & 0.296 & 0.306 \\
\hline $60-89$ & $5(8.5 \%)$ & $29(49.2 \%)$ & $7(11.9 \%)$ & $18(30.5 \%)$ & & & & \\
\hline \multicolumn{9}{|l|}{ FSLP (mmo/l) } \\
\hline Choll T $\operatorname{des}(<5.2)$ & $14(13.0 \%)$ & $48(44.4 \%)$ & $24(22.2 \%)$ & $22(20.4 \%)$ & 28.424 & 6 & $<0.001$ & $<0.001$ \\
\hline $\mathrm{bL}(5.2-6.2)$ & $0(0.0 \%)$ & $6(40.0 \%)$ & $0(.0 .0 \%)$ & $9(60.0 \%)$ & & & & \\
\hline $\operatorname{High}(>6.2)$ & $0(0.0 \%)$ & $3(23.1 \%)$ & $0(0)$ & $10(76.9 \%)$ & & & & \\
\hline LDL $\operatorname{des}(<2.6)$ & $11(18.9 \%)$ & $22(33.8 \%)$ & $19(29.2 \%)$ & $13(20.5 \%)$ & 31.318 & 6 & $<0.001$ & $<0.001$ \\
\hline $\mathrm{bL}(2.6-4.1)$ & $3(5.8 \%)$ & $29(55.8 \%$ & $5(9.6 \%)$ & $15(28.8 \%)$ & & & & \\
\hline $\operatorname{High}(>4.1)$ & $0(0.0 \%)$ & $6(31.6 \%)$ & $0(0.0 \%)$ & $13(68.4 \%)$ & & & & \\
\hline HDL $\operatorname{des}(<1.0)$ & $11(14.7 \%)$ & $43(57.3 \%)$ & $10(13.3 \%)$ & $11(14.7 \%)$ & 27.649 & 3 & $<0.001$ & $<0.001$ \\
\hline $\operatorname{High}(>1.0)$ & $3(4.9 \%)$ & $14(23.0 \%)$ & $14(23.0 \%)$ & $30(49.1 \%)$ & & & & \\
\hline TG $\operatorname{des}(<1.7)$ & $14(11.1 \%)$ & $54(42.9 \%)$ & $24(19.0 \%)$ & $34(27.0 \%)$ & 21.044 & 6 & 0.001 & 0.002 \\
\hline bL(1.7-2.2) & $0(0.0 \%)$ & $3(100 \%)$ & $0(0.0 \%)$ & $0(0.0 \%)$ & & & & \\
\hline $\operatorname{High}(>2.2)$ & $0(0.0 \%)$ & $0(0.0 \%)$ & $0(0.0 \%)$ & $7(100 \%)$ & & & & \\
\hline
\end{tabular}

$\Lambda^{2}=$ chi square, $\mathrm{LHR}=$ likelihood ratio, $\mathrm{ClCr}=$ creatinine clearance, $24 \mathrm{HUP}=24$-hor urine protein, FSLP=fasting serum ; $[$ id profile, CholT=serum total cholesterol, $\mathrm{LDL}=$ serum low density lipoprotein cholesterol, $\mathrm{HDL}=$ serum high density lipoprotein cholesterol, TG=serum triglyceride, des=desirable level, $\mathrm{bL}=$ borderline, $\mathrm{Hb}=$ hemoglobin, $\mathrm{df}=$ degree of freedom, 24HUOsm=24-hour urine osmolality, 


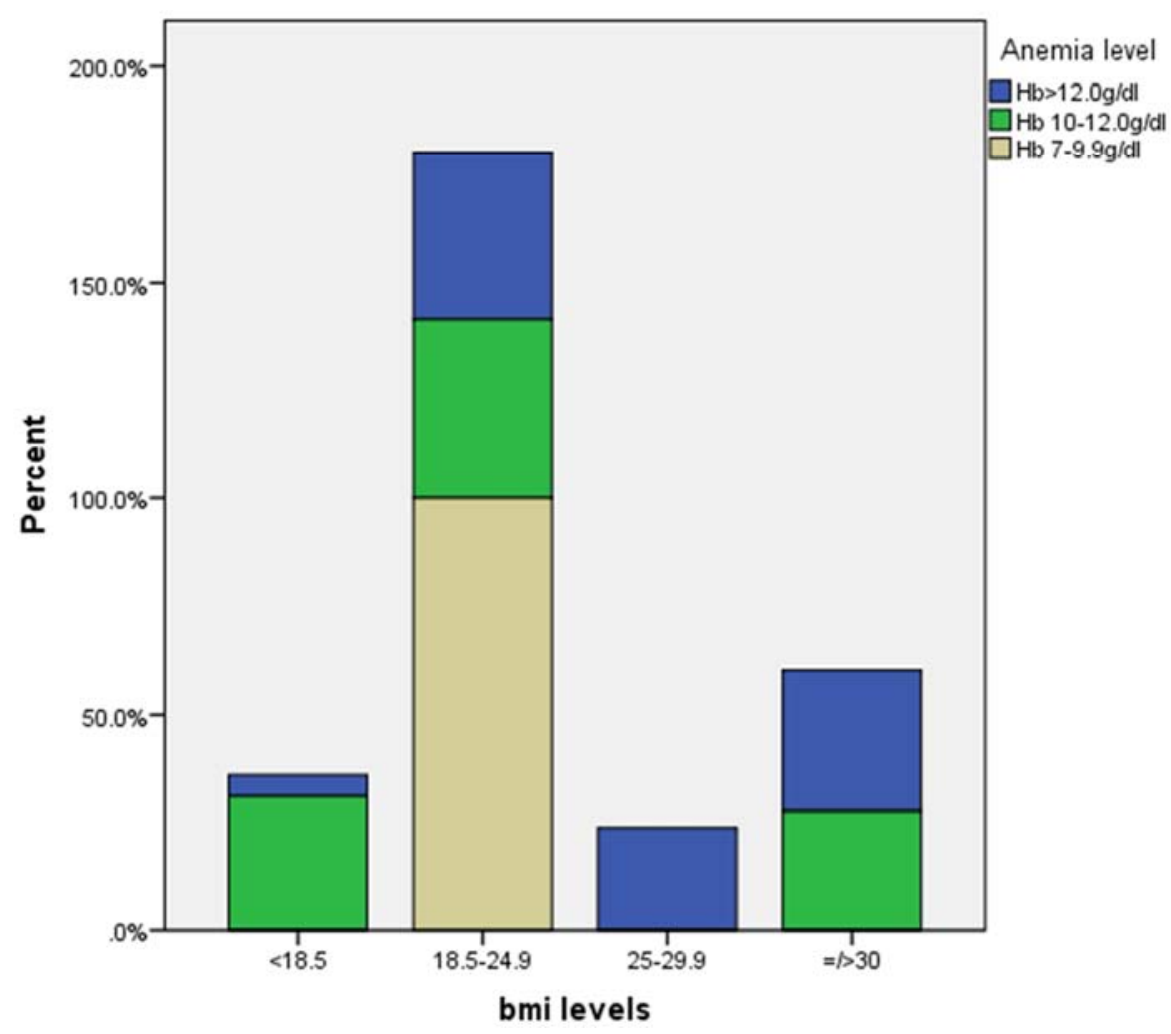

Figure 1. Association between BMI and Anemia

Significant association was observed between BMI and 24HUOsm, $(\mathrm{df}=3, \mathrm{p}=0.002)$. Among 122 subjects with $24 \mathrm{HUOsm}$ $<300 \mathrm{mOsm} / \mathrm{kgH}_{2} \mathrm{O}, 7.4 \%$ has BMI $<18.5 \mathrm{~kg} / \mathrm{m}^{2}, 44.3 \%$ has BMI $18.5-24.9 \mathrm{~kg} / \mathrm{m}^{2}, 19.7 \%$ has BMI $25.0-29.9 \mathrm{~kg} / \mathrm{m}^{2}$, while $28.7 \%$ has $\mathrm{BMI} \geq 30.0 \mathrm{~kg} / \mathrm{m}^{2}$. This demonstrated that the prevalence of dilute urine declined with underweight and obesity. None of the subjects has concentrated urine (Table 2, Figure 2).

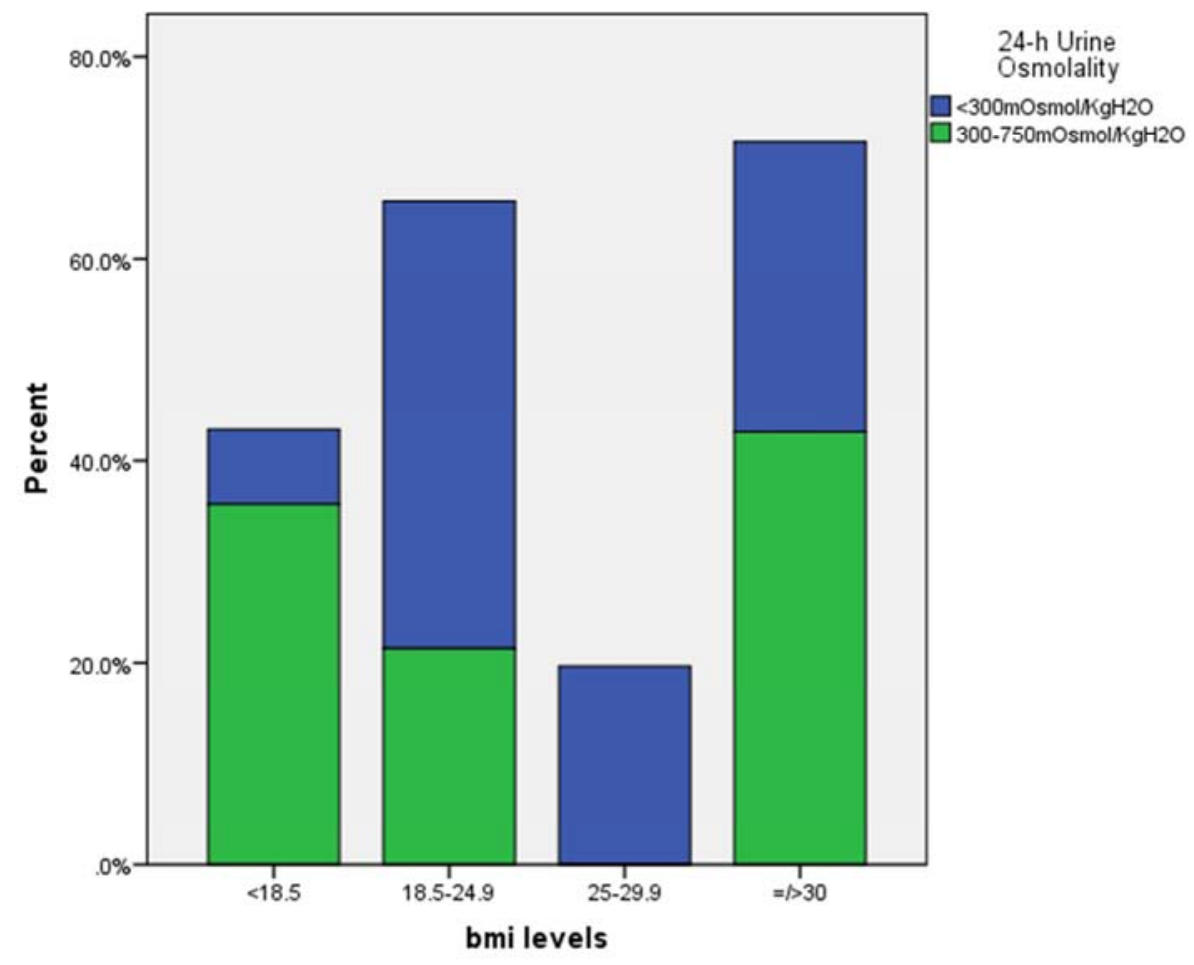

Figure 2. Association between BMI and 24-hour urine osmolality. 
Serum cholesterol has significant association with BMI, $(\mathrm{df}=6, \mathrm{p}<0.001)$. Out of 108 subjects with desirable serum cholesterol level $(<5.2 \mathrm{mmol} / 1), 13.0 \%$ has BMI $<18.5 \mathrm{~kg} / \mathrm{m}^{2}$, while $20.4 \%$ has BMI $\geq 30.0 \mathrm{~kg} / \mathrm{m}^{2}$. Among 15 with borderline serum cholesterol level $(5.2-6.2 \mathrm{mmol} / \mathrm{l})$, none has BMI $<18.5 \mathrm{~kg} / \mathrm{m}^{2}$ while $60.0 \%$ has BMI $\geq 30.0 \mathrm{~kg} / \mathrm{m}^{2}$. Similarly, out of 13 subjects with high serum cholesterol level $(>6.2 \mathrm{mmol} / \mathrm{l})$, none has BMI $<18.5 \mathrm{~kg} / \mathrm{m}^{2}$, while $76.9 \%$ has BMI $\geq 30.0 \mathrm{~kg} / \mathrm{m}^{2}$. This showed that the prevalence of hypercholesterolemia declined with underweight but increased with obesity (Table 2).

There was significant association between BMI and serum LDL, $(\mathrm{df}=6, \mathrm{p}<0.001)$. Out of 52 subjects with borderline serum LDL $(2.6-4.1 \mathrm{mmol} / 1), 5.8 \%$ has BMI $<18.5 \mathrm{~kg} / \mathrm{m}^{2}$ while $29.9 \%$ has BMI $\geq 30$. Similarly, out of 19 subjects with high serum LDL $(>4.1 \mathrm{mmol} / \mathrm{l})$, none has BMI $<18.5 \mathrm{~kg} / \mathrm{m}^{2}$ while $68.4 \%$ has BMI $\geq 30.0 \mathrm{~kg} / \mathrm{m}^{2}$. This showed that the prevalence of LDL hypercholesterolemia declined with underweight but increased with obesity (Table 2, Figure 3).

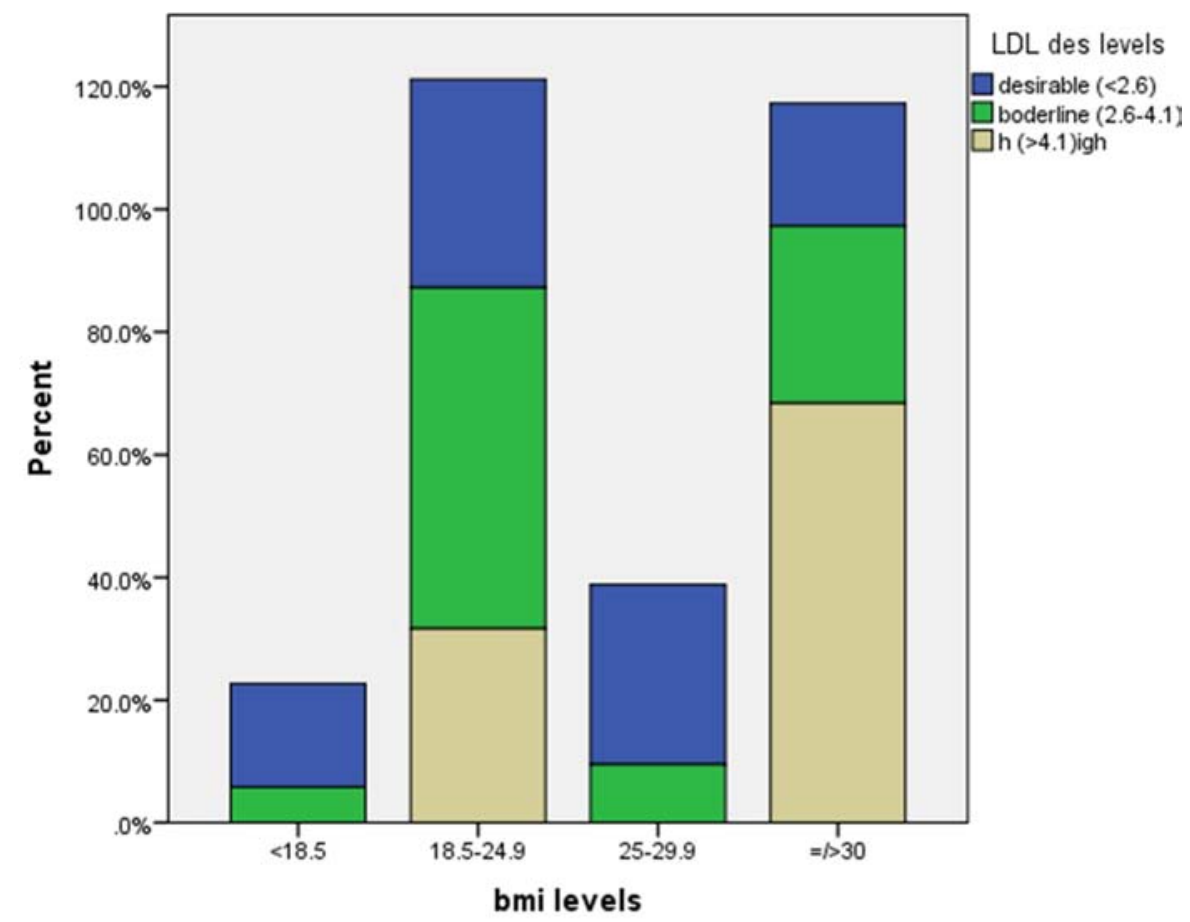

Figure 3. Association between BMI and serum $L D L$.

The association between BMI and serum HDL was significant, $(\mathrm{df}=3, \mathrm{p}<0.001)$. Among 75 subjects with serum HDL $<1.0 \mathrm{mmol} / 1,14.7 \%$ has $\mathrm{BMI}<18.5 \mathrm{~kg} / \mathrm{m}^{2}$ and $\mathrm{BMI} \geq$ $30.0 \mathrm{~kg} / \mathrm{m}^{2}$. However, among 61 subjects with high serum HDL $\geq 1.0 \mathrm{mmol} / 1,4.9 \%$ has BMI $<18.5 \mathrm{~kg} / \mathrm{m}^{2}$ while $49.1 \%$ has $\mathrm{BMI} \geq 30.0 \mathrm{~kg} / \mathrm{m}^{2}$. This showed that the prevalence of abnormal serum HDL declined with underweight and obesity (Table 2).

Serum triglyceride and BMI have significant association, $(\mathrm{df}=6, \mathrm{p}=0.002)$. Among 126 subjects with desirable serum triglyceride $(<2.6 \mathrm{mmol} / 1), 11.1 \%$ has $\mathrm{BMI}<18.5 \mathrm{~kg} / \mathrm{m}^{2}$ while $27.0 \%$ has $\mathrm{BMI} \geq 30.0 \mathrm{~kg} / \mathrm{m}^{2}$. None of the 3 subjects with borderline serum triglyceride $(2.6-4.1 \mathrm{mmol} / \mathrm{l})$ has BMI $<18.5 \mathrm{~kg} / \mathrm{m}^{2}$ or $\mathrm{BMI} \geq 30.0 \mathrm{~kg} / \mathrm{m}^{2}$. However, all 7 subjects with high serum triglyceride have BMI $\geq 30.0 \mathrm{~kg} / \mathrm{m}^{2}$. This demonstrated that hypertriglyceridemia was absent in underweight subjects but prevalent in those obese (Table 2).

No significant association was observed between BMI and 24HUP (df=9, p=0.299), $\mathrm{ClCr}(\mathrm{df}=3, \mathrm{p}=0.306)$ (Table 2).

BMI showed significant correlation with SUP $(r=0.32$, $\mathrm{p}<0.001), \quad$ SUCr $\quad(\mathrm{r}=0.21, \quad \mathrm{p}=0.009), \quad$ SUOsm $\quad(\mathrm{r}=0.24$, $\mathrm{p}=0.005)$, serum cholesterol $(\mathrm{r}=0.34, \quad \mathrm{p}<0.001)$, serum triglyceride $\quad(\mathrm{r}=0.30, \mathrm{p}<0.001), \quad$ serum $\mathrm{HDL} \quad(\mathrm{r}=0.43$, $\mathrm{p}<0.001)$, serum LDL $(\mathrm{r}=0.19, \mathrm{p}=0.023), \mathrm{Hb} \quad(\mathrm{r}=0.21$, $\mathrm{p}=0.015)$. There was no significant correlation between BMI and serum creatinine, 24HUV, 24HUP, 24HUCr, 24HUOsm, as well as $\mathrm{ClCr}$ (Table 3).

Table 3. Correlation of BMI with potential risk factors in study subjects $(n=136)$.

\begin{tabular}{lll}
\hline Variables & Correlation coefficient(r) & P value \\
\hline Spot urine protein & 0.32 & $<0.001$ \\
Spot urine creatinine & 0.23 & 0.009 \\
Spot urine osmolality & 0.24 & 0.005 \\
24-hour urine protein & 0.05 & 0.595 \\
24-hour urine creatinine & 0.06 & 0.520 \\
24-hour urine osmolality & -0.03 & 0.728 \\
24HUV & 0.08 & 0.389 \\
Serum creatinine & 0.14 & 0.100 \\
Serum cholesterol (total) & 0.34 & $<0.001$ \\
Serum Triglyceride & 0.30 & $<0.001$ \\
Serum HDL & 0.43 & $<0.001$ \\
Serum LDL & 0.20 & 0.023 \\
Creatinine clearance & -0.08 & 0.374 \\
Hemoglobin & 0.21 & 0.015 \\
\hline
\end{tabular}

BMI=body mass index, HDL=high density lipoprotein cholesterol, LDL=low density lipoprotein cholesterol 
Multivariate linear regression analysis of BMI with potential risk factors showed that SUP, SUOsm, and $\mathrm{Hb}$ predicted BMI while SUCr, serum cholesterol, serum triglyceride, serum HDL, and serum HDL did not (Table 4).

Table 4. Multivariate linear regression of BMI with potential risk factors in study subjects $n=136$.

\begin{tabular}{lllll}
\hline Variables & Beta & T & P value & $\mathbf{9 5 \%}$ CI \\
\hline Spot urine protein & 0.303 & 4.009 & $<0.001$ & $0.054-0.160$ \\
Spot urine creatinine & 0.015 & 0.192 & 0.848 & $-0.005-0.007$ \\
Spot urine osmolality & 0.238 & 3.267 & 0.001 & $0.003-0.012$ \\
Serum cholesterol & 0.462 & 1.676 & 0.096 & $-0.011-0.135$ \\
Serum triglyceride & 0.047 & 0.475 & 0.635 & $-0.027-0.045$ \\
Serum LDL & -0.331 & -1.347 & 0.180 & $-0.128-0.024$ \\
Serum HDL & 0.251 & 2.159 & 0.033 & $0.010-0.234$ \\
Hemoglobin & 0.237 & 3.424 & 0.001 & $0.405-1.514$ \\
\hline
\end{tabular}

$\mathrm{CI}=$ Confidence Interval. $\mathrm{HDL}=$ high density lipoprotein cholesterol, $\mathrm{LDL}=$ low density lipoprotein cholesterol, $\mathrm{BMI}=$ body mass index $\mathrm{R}^{2}=0.383$ df 8 ANOVA $\mathrm{p}<0.001$

Further multivariate linear regression analysis of underweight $\left(\mathrm{BMI}<18.5 \mathrm{~kg} / \mathrm{m}^{2}\right)$ and obesity (BMI $\geq 30.0 \mathrm{~kg} / \mathrm{m}^{2}$ ) with potential risk factors showed that SUOsm, serum cholesterol, serum HDL and serum LDL predicted obesity, while SUP, SUCr, serum triglyceride and $\mathrm{Hb}$ did not (Tables 5).

Table 5. Multivariate linear regression of obesity $\left(B M I>30 \mathrm{~kg} / \mathrm{m}^{2)}\right)$ with potential risk factors in study subjects $n=41$.

\begin{tabular}{lllll}
\hline Variables & Beta & T & P value & 95\% CI \\
\hline Spot urine protein & 0.302 & 1.645 & 0.110 & $-0.009-0.086$ \\
Spot urine creatinine & -0.055 & -0.258 & 0.798 & $-0.010-0.008$ \\
Spot urine osmolality & 0.465 & 2.899 & 0.007 & $0.002-0.011$ \\
Serum cholesterol & 1.873 & 2.498 & 0.018 & $0.035-0.346$ \\
Serum triglyceride & $<0.001$ & 0.002 & 0.999 & $-0.044-0.044$ \\
Serum LDL & -1.748 & -2.398 & 0.023 & $-0.284--0.023$ \\
Serum HDL & -0.704 & -2.632 & 0.013 & $-0.354--0.045$ \\
\hline Hemoglobin & 0.203 & 0.994 & 0.327 & $-0.720-2.095$ \\
\hline
\end{tabular}

$\mathrm{CI}=$ Confidence Interval. $\mathrm{HDL}=$ high density lipoprotein cholesterol, $\mathrm{LDL}=$ low density lipoprotein cholesterol, $\mathrm{BMI}=$ body mass index $\mathrm{R}^{2}=0.401$ df 8 ANOVA 0.022

Regression of underweight with variables was voided as the colinearity variance was skewed due to the small subset population.

\section{Discussion}

This study showed that the prevalence of underweight was $10.3 \%$, overweight $17.6 \%$ and obesity $30.1 \%$ in the subjects. There was significant association between BMI and $\mathrm{Hb}$, 24HUOsm, serum cholesterol, serum LDL, serum HDL, as well as serum triglyceride. There was significant but poor correlation between BMI and SUP, SUCr, SUOsm, serum cholesterol, serum triglyceride, serum HDL, serum LDL, Hb. Spot urine protein, SUOsm, and $\mathrm{Hb}$ were predictors of BMI, while SUOsm, serum cholesterol, serum HDL, and serum LDL were predictors of obesity.

The prevalence $10.3 \%$ of underweight in subjects attending the general out-patient clinic observed in this study is similar to $6.1 \%$ reported by Anyabolu EN [25] in treatment-naïve HIV subjects despite the difference in the HIV status of the subjects in this study. In contrast, this is higher than the $2.5 \%$ documented by Chukwuonye et al [16] in Abia State, Nigeria. Both studies were done in the same Southeast geopolitical zone of Nigeria. However, the difference in prevalence might be explained by the slight difference in study design. Their study subjects were urban and rural dwellers drawn from the communities, while ours comprised of subjects attending the general out-patient clinic. In addition, factors related to illnesses for which the patients presented in out-patient clinic might account for the higher prevalence observed in our study. At the other pole, one study reported a much higher underweight prevalence of $22.7 \%$ in rural dwellers in India, among a low-resource income population. [10] Our study did not evaluate the association of underweight with socioeconomic status.

It was observed in this study that the prevalence $17.6 \%$ of overweight was similar to that in a multi-center, Nigerian study of urban dwellers. [9] It was, however, lower than the $28.2 \%$ and $38.4 \%$ reported in two Nigerian studies. [16, 25] The first study was community-based, the second HIV clinicbased, while ours was hospital-based: this might be the reason for the difference in the prevalence of overweight compared to that noted in our study.

This study observed a prevalence $30.1 \%$ of obesity, a value much higher than those reported in Nigeria and India. $[9,10$, $16,20]$ Unlike our study which was carried out in an outpatient clinic, these studies were community-based with much larger population sizes.

This study found a significant association between BMI and $\mathrm{Hb}$. Hemoglobin was a predictor of BMI, but did not predict isolated underweight or obesity. Nonetheless, it demonstrated that the prevalence of anemia increased with underweight but declined with obesity. This agrees with the reports that demonstrated an association between anemia and weight changes in HIV subjects. [25, 26] This demonstrated that anemia was a risk factor of underweight irrespective of the setting in which underweight occurred.

In this study, significant association was observed between BMI and 24HUOsm, $(\mathrm{df}=3, \mathrm{p}=0.002)$. It further demonstrated that the prevalence of dilute urine declined with underweight and obesity. It was also observed that SUOsm was a predictor of obesity. Dilute urine may be seen in renal damage involving the interstitial compartment and the tubules, suggesting that among our study subjects, those with obesity were more likely to have renal damage. Two studies, however, reported an association between 24HUOsm and BMI, though one was in HIV subjects. [21, 25]

It was noted in this study that serum cholesterol has 
significant association with $\mathrm{BMI},(\mathrm{df}=6, \mathrm{p}<0.001)$. It also demonstrated that the prevalence of hypercholesterolemia declined with underweight but increased with obesity. It further showed that serum cholesterol predicted obesity. This agrees with the studies that associated hypercholesterolemia with obesity. [27, 28]

This study found a significant association between BMI and serum $\mathrm{LDL},(\mathrm{df}=6, \mathrm{p}<0.001)$, and further demonstrated that the prevalence of LDL hypercholesterolemia declined with underweight but increased with obesity. It was also observed that it predicted obesity. This is in agreement with reports that have shown an association between obesity and LDL hypercholesterolemia. [29, 30] Serum LDL is the major determinant of serum total cholesterol, and therefore increases as serum total cholesterol increases. [30]

The association between BMI and serum HDL was significant, $(\mathrm{df}=3, \mathrm{p}<0.001)$, as found in this study. It was also observed that abnormal serum HDL occurred more in underweight subjects, contrary to the report documented in another study that showed an association between abnormal HDL and obesity. [30] Serum HDL predicted obesity in this study. Perhaps, our study subjects might have other morbidities that could account for this contrast, as they were patients presenting in the out-patient clinic.

This study showed that serum triglyceride and BMI have significant association. It was further observed that hypertriglyceridemia was absent in underweight subjects but prevalent in those obese. Our study also noted that serum triglyceride was a predictor of obesity. This contrasts with another study that found no association between serum triglyceride and BMI. [25] On the contrary, one study observed that serum triglyceride increased with obesity.[31]

Spot urine protein was a predictor of BMI in this study. This implied that proteinuria would increase with increasing weight but decline with decreasing weight. A study demonstrated a similar observation that the prevalence of proteinuria increased with underweight as well as with obesity.[25] This held sway despite the difference in the study population; ours were out patients that presented in an out-patient clinic, while theirs were HIV subjects presenting in the early stage of the disease in an HIV clinic.

\section{Conclusion}

The prevalence of underweight (10.3\%) and obesity $(30.1 \%)$ were high in the general out patients. Abnormalities of serum lipids, proteinuric renal disease with dilute urine were common in these subjects. There is a need for clinicians to routinely assess BMI and further search for anemia, lipid and proteinuric renal abnormalities in subjects with underweight and obesity attending the general out-patient clinics.

\section{Limitations}

The study population was small. A much larger study sample size would have been better as it would averted the skewed colinearity variance that voided the regression analysis of underweight with its potential risk factors. In addition, some elements of association of BMI with concentrated urine would have been observed.

\section{References}

[1] Barness LA, Opitz JM, Gilbert-Barness E. Obesity: Genetic, molecular, and environmental aspects. Am J Med Genet A. 2007; 143A (24): 3016-3034.

[2] World Health Organization. Obesity and overweight fact sheet. IOTF report. 2015. Available at http://www.who.int/mediacentre/factsheets/fs311/en/.

[3] Popkin BM, Adair LS, Wen Ng S. NOW AND THEN: The Global Nutrition Transition: The Pandemic of Obesity in Developing Countries. Nutr Rev. 2012 Jan; 70(1): 3-21. doi: 10.1111/j.1753-4887.2011.00456.

[4] Segula D (2014) Complications of obesity in adults: A short review of the literature. Malawi Med J 26: 20-24.

[5] Ungefroren H, Gieseler F, Fliedner S, Lehnert H (2015) Obesity and cancer. Horm Mol Biol Clin Investig 21: 5-15.

[6] Iloh GUP, Ikwudinma AO, Obiegbu NP (2013) Obesity and Its Cardio-metabolic Co-morbidities Among Adult Nigerians in a Primary Care Clinic of a Tertiary Hospital in South-Eastern, Nigeria. J Family Med Prim Care 2: 20-26.

[7] Hummen R, Syrjanen J (2013) Obesity and the risk and outcome of infection. Int J Obes (Lond) 37: 333-340.

[8] Nguyen DM, El-Serag HB. The Epidemiology of Obesity. Gastroenterol Clin North Am. 2010 Mar; 39(1): 1-7. doi: 10.1016/j.gtc.2009.12.014.

[9] Okafor C I, Gezawa I D, Sabir A A, Raimi T H, Enang O. Obesity, overweight, and underweight among urban Nigerians. Niger J Clin Pract [serial online] 2014 [cited 2016 Sep 28]; 17:743-9.

http://www.njcponline.com/text.asp?2014/17/6/743/144389

[10] Little M, Humphries S, Patel K, Dewey C. Factors associated with BMI, underweight, overweight, and obesity among adults in a population of rural south India: a cross-sectional study. BMC Obes. 2016; 3: 12. doi: 10.1186/s40608-016-0091-7.

[11] Obesity and overweight Fact sheet Updated June 2016 http://www.who.int/mediacentre/factsheets/fs311/en/.

[12] Chukwuonye II, Chuku A, John C, Ohagwu KA, Imoh ME, et al. (2013) Prevalence of overweight and obesity in adult Nigerians - a systematic review. Diabetes Metab Syndr Obes 6: 43-47.

[13] Gezawa ID, Musa BM, Mijinyawa MS, Talle MA, Shehu YM, et al. (2014) Prevalence of hypertension and its relationship with indices of obesity in Maiduguri, Northeastern Nigeria. Niger J Basic Clin Sci 11: 67-71.

[14] Wahab KW, Sani MU, Yusuf BO, Gbadamosi M, Gbadamosi A, et al. (2011) Prevalence and determinants of obesity - a cross-sectional study of an adult Northern Nigerian population. Int Arch Med 4: 10.

[15] Amira CO, Sokunbi DOB, Dolapo D, Sokunbi A (2011) Prevalence of obesity, overweight and proteinuria in an urban community in South West Nigeria. Nigerian Medical Journal 52: 110-113. 
[16] Chukwuonye II, Chuku A, Onyeonoro U, Ukegbu A, Anyabolu E, et al. (2015) Body Mass Index, Prevalence and Predictors of Obesity in Urban and Rural Communities in Abia State South Eastern Nigeria. J Diabetes Metab 6: 570. doi:10.4172/2155-6156.1000570.

[17] Mataix J, López-Frías M, Martínez-de-Victoria E, LópezJurado M, Aranda P, Llopis J. Factors associated with obesity in an adult Mediterranean population: influence on plasma lipid profile. J Am Coll Nutr. 2005 Dec; 24(6):456-65.

[18] Ly KA, †Email author, Ton TG†, Ngo QV, Vo TT, Fitzpatrick AL. Double burden: a cross-sectional survey assessing factors associated with underweight and overweight status in Danang, Vietnam. BMC Public Health201313:35. DOI: 10.1186/14712458-13-35.

[19] Anyabolu EN, Chukwuonye II, Arodiwe E, Ijoma CK, Ulasi I. Prevalence and predictors of chronic kidney disease in newly diagnosed human immunodeficiency virus patients in Owerri, Nigeria. Indian J Nephrol 2016; 26:10-5.

[20] Anyabolu EN, Chukwuonye II, Mabayoje M, Ejike A, Ijoma CK, Oviasu E, Kadiri S.. Comparison of Spot Urine Protein/Creatinine Ratio, Spot Urine Protein/Osmolality Ratio with Measured 24-Hour Urine Protein in HIV Subjects in Nigeria. J AIDS Clin Res 2015; 6: 445. doi:10.4172/21556113.1000445 .

[21] Anyabolu EN, Chukwuonye II. Urine Osmolality in Adults Attending a General out-Patient Clinic: Clinical Implications. American Journal of Medicine and Medical Sciences 2016, 6(5): 145-151. DOI: 10.5923/j.ajmms.20160605.01.

[22] WHO (1995) Physical Status: The Use and Interpretation of Anthropometry. Technical Report Series 854, 1-1-9950. World Health Organization, Geneva.

[23] Yeh HC, Lin YS, Kuo CC, Weidemann D, Weaver V, Fadrowski J, Neu A, Navas-Acien A. Urine osmolality in the US population: implications for environmental biomonitoring.
Environ Res. 2015 Jan; 136:482-90. doi: 10.1016/j.envres.2014.09.009. Epub 2014 Nov 25.

[24] Hemoglobin concentrations for the diagnosis of anemia and assessment of severity VMNIS | Vitamin and Mineral Nutrition Information System WHO/NMH/NHD/MNM/11.1.

[25] Anyabolu, E. N. (2016) BMI and Risk Factors of Underweight and Obesity in HIV Subjects in Eastern Nigeria. World $\begin{array}{llll}\text { Journal of } & \text { AIDS, } & 6,15 \text {. }\end{array}$ http://dx.doi.org/10.4236/wja.2016.61002.

[26] Mariz Cde A, Albuquerque Mde F, Ximenes RA, Melo HR, Bandeira F, Oliveira TG, Carvalho EH, Silva AP, Miranda Filho Dde B. Body mass index in individuals with HIV infection and factors associated with thinness and overweight/obesity. Cad Saude Publica. 2011 Oct; 27(10):1997-2008.

[27] Tanner JM. The relation between serum cholesterol and physique in healthy young men. J Physiol 115: 371, 1951.

[28] Montoye HI, Epstein FH, Kjelsberg MO. Relationship between serum cholesterol and body fatness. Amer J Clin Nutr 18: 397, 1966.

[29] Kesaniemi YA, Grundy SM. Increased low density lipoprotein production associated with obesity. Arteriosclerosis. 1983 Mar-Apr;3(2):170-7.

[30] Ruel IL, Gaudet D, Perron P, Bergeron J, Julien P, Lamarche B. Effect of obesity on HDL and LDL particle sizes in carriers of the null P207L or defective D9N mutation in the lipoprotein lipase gene: the Québec LipD Study. International Journal of Obesity (2003) 27, 631-637. doi:10.1038/sj.ijo.0802276.

[31] Després JP, Moorjani S, Tremblay A, Ferland M, Lupien PJ, Nadeau A, Bouchard C. Relation of high plasma triglyceride levels associated with obesity and regional adipose tissue distribution to plasma lipoprotein-lipid composition in premenopausal women. Clin Invest Med. 1989 Dec;12(6):374-80. 